\title{
How does the context and design of participatory decision making processes affect their outcomes? Evidence from sustainable land management in global drylands
}

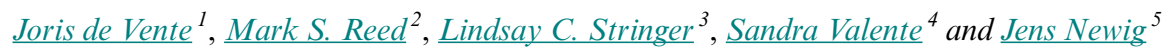

\begin{abstract}
Although the design of participatory processes to manage social-ecological systems needs to be adapted to local contexts, it is unclear which elements of process design might be universal. We use empirical evidence to analyze the extent to which context and process design can enable or impede stakeholder participation and facilitate beneficial environmental and social outcomes. To explore the role of design and minor variations in local context on the outcomes of participatory processes, we interviewed participants and facilitators from 11 case studies in which different process designs were used to select sustainable land management options in Spain and Portugal. We analyzed interview data using quantitative and qualitative approaches. Results showed that although some aspects of local context affected process outcomes, factors associated with process design were more significant. Processes leading to more beneficial environmental and social outcomes included the following: the legitimate representation of stakeholders; professional facilitation including structured methods for aggregating information and balancing power dynamics among participants; and provision of information and decision-making power to all participants. Although processes initiated or facilitated by government bodies led to significantly less trust, information gain, and learning, decisions in these processes were more likely to be accepted and implemented. To further test the role of context in determining the outcomes of participation, we interviewed facilitators from a process that was replicated across 13 dryland study sites around the world, reflecting much greater national variations in context. The similarity of outcomes across these sites suggested that the socio-cultural context in which the process was replicated had little impact on its outcomes, as long as certain design principles were fulfilled. Overall, our findings provide a solid empirical basis for good practice in the design of participatory processes in the management of social-ecological systems.
\end{abstract}

Key Words: drylands; environmental management; land degradation; social learning; stakeholder engagement; sustainable land management

\section{INTRODUCTION}

Scientists and policy makers managing social-ecological systems are increasingly encouraged to use participatory approaches. Claims in support of participation are bold. Engaging with stakeholders offers the promise of achieving environmental goals more efficiently and effectively. It helps to reduce and resolve conflict by building trust and learning among stakeholders. This increases the likelihood that stakeholders will support project goals and implement decisions in the long term (Macnaghten and Jacobs 1997, Beierle 2002, Dietz and Stern 2008, Reed 2008). However, there is concern that many of the claimed benefits are not being realized. Some critics, for example, discuss how problems with stakeholder representation or participatory process design and implementation mean processes fail to achieve their goals. Participatory processes can also exacerbate conflict, or allow special interest groups to bias outcomes (Coglianese 1997, Cook and Kothari 2001, Gerrits and Edelenbos 2004, Scott 2011). Others emphasize the limited success of collaborative natural resource management, especially when the causes and effects of environmental problems reach beyond local boundaries. This underlines the importance of social and institutional complexity, the institutional scale, and the context in which the process is performed (Singleton 2002, Ferreyra et al. 2008, Armitage et al. 2012).
The outputs, e.g., strategies, plans, or other agreements, and ultimate outcomes, e.g., social learning, network forming, preference change, or implementation of solutions, of participatory processes in management of social-ecological systems depend highly on the selection of participants, the process design, and the socio-cultural, institutional, and environmental context in which they are conducted. Cuppen (2012) found that social learning from participatory processes (using Reed et al's. 2010 definition of social learning as "a change in understanding that goes beyond the individual to become situated within wider social units or communities of practice through social interactions between actors within social networks") was dependent upon the diversity of perspectives held by those who engaged in the process. Similarly, Newig and Fritsch (2009a) found that the composition of groups engaging in participatory processes and their associated preferences strongly influenced the environmental standard of outputs and outcomes. Others point to the importance of systematically identifying and selecting stakeholders for inclusion as a prerequisite for achieving desired outputs and outcomes (Reed et al. 2009, Stanghellini 2010). Various studies have focused on the context of participation, such as cultural barriers to successful participation in former communist states (Stringer et al. 2009, Blicharska et al. 2011). Koontz (2005) found that the degree to which collaborative

${ }^{1}$ Spanish National Research Council (CEBAS-CSIC), ${ }^{2}$ Institute for Agri-Food Research and Innovation and Centre for Rural Economy, School of Agriculture, Food and Rural Development, Newcastle University, ${ }^{3}$ Sustainability Research Institute, School of Earth and Environment, University of Leeds, ${ }^{4}$ Centre for Environmental and Marine Studies (CESAM), Department of Environment and Planning, University of Aveiro, ${ }^{5}$ Leuphana University Lüneburg, Research Group Governance, Participation and Sustainability 
planning led to policy change was determined largely by local contextual factors rather than by the design of the participatory process.

The research we present in this paper contributes to debates surrounding the challenges and opportunities linked to participation. We consider how participatory approaches to management of social-ecological systems (1) result in better informed and sustainable environmental decisions or policies, facilitate their acceptance and implementation, and thus achieve environmental goals more effectively, and (2) benefit participants in other ways linked to the participatory process, for example, through increased learning and trust, and achieve their stated goals, whether environmentally related or not.

Previous attempts to critically analyze participation have typically been based on qualitative case study approaches or on comparisons of cases in very different contexts (Newig 2012). Most studies focus on evaluating the process of participation rather than its outcomes (Renn et al. 1995, Beierle 1999). Here, we seek to make an important contribution by explicitly linking the process of participation with its outcomes, carefully considering the extent to which process design and local versus national context influence these outcomes. We use the term "outcomes" to cover outputs and outcomes as defined above.

\section{RESEARCH DESIGN}

To disentangle the effects that process design and context may have on the outcomes of participatory processes, we collected and analyzed empirical data from two groups of projects tackling dryland degradation, using quantitative and qualitative techniques. In the first group, the national context in which participation took place was constant, the local context showed some variation, but the level of participation and the design of the processes differed markedly. Analysis of these cases provided insight into the effects of process design and minor variations in local context on process outcomes. In the second group of projects, the same participatory process was replicated across markedly different national decision-making contexts in different countries around the world. Analysis of these cases provided insight into the robustness of process design principles under very different contexts.

Regarding quantitative techniques, we used descriptive statistics and correlation analysis to identify the key factors influencing the environmental and social outcomes of participation. In doing this we explicitly recognize that we are analyzing people's perceptions, and that different factors combine to influence those perceived outcomes. We then take an interpretivist approach by using qualitative in-depth interview data to interpret the statistical relationships derived from the quantitative analysis, as far as possible through the eyes of the respondents. By taking a grounded theory approach to the analysis of these interviews (Corbin and Strauss 1990), whereby emergent theory comes from the data through iterative analysis, it provides us with insight into the roles of context and process in participatory practice (Cook and Wagenaar 2012).

\section{Methodology}

Case study selection and characterization

First, we evaluated the role of process design and minor variations in local contextual factors in determining the outcomes of 11 cases of participatory decision making in Spain and Portugal. These cases all aimed to tackle environmental degradation, soil and water conservation, and sustainable land management (SLM) of agriculture and forestry in semiarid to dry subhumid environments. These cases reflect different levels, methods, and design of participation, illustrated by three classification schemes (Table 1 and Box 1). In these cases, we expected the outcomes of participation to be dominated by differences in process design and local context, rather than by differences in national context (Newig and Fritsch 2009b). By analyzing interviews with participants and facilitators of these cases, we highlight the effects of process design and minor variations in local context on the outcomes of participation.

\section{Box 1:}

Classification schemes of stakeholder participation.

We used three classification schemes to characterize the type and level of participation in the Spanish and Portuguese cases (Table 1). First, Pretty's (1995) scheme describes a continuum of increasing stakeholder involvement, from passive dissemination of information, to active engagement. Although recently, Hurlbert and Gupta (2015) have conceptualized this continuum as a "split ladder" of participation, recognizing that low levels of participation may be acceptable or even desirable in contexts where little disagreement exists and decisions can be made easily without reference to stakeholders. Collins and Ison (2009) suggest that we need to "jump off the ladder" to focus on social learning among multiple actors. Second, Rowe and Frewer (2000) classify stakeholder engagement according to the direction of communication between parties. They labelled information dissemination to passive recipients as "communication," gathering information from participants as "consultation," while "participation" was conceptualized as a two-way communication and learning process between all participants and process organizers. Third, Fung (2006) distinguished three dimensions of participation: (1) who participates, (2) how participants communicate with one another and make decisions, and (3) how process outcomes are linked with policy or public action. Who participates is ranked from more restrictive to more inclusive approaches, forms of communication are ranked from more to less intense, and the links with policy or public action are grouped from least to most authority.

Second, we examined the role of national context in determining outcomes of participation by evaluating the outcomes of a participatory process replicated in 13 dryland study sites around the world as part of the DESIRE research project (Table 2). The DESIRE project aimed to (1) combine local and scientific knowledge to select effective and socially accepted SLM options for land managers, (2) facilitate mutual learning through dialogue between stakeholder groups to achieve awareness, understanding, and ownership over land degradation problems and SLM solutions, and (3) implement, monitor, and demonstrate the effectiveness and feasibility of SLM to strengthen social acceptance. In each of the DESIRE sites, the same participatory process design, as detailed in other publications (Schwilch et al. 2009), was used in each country (with minor variations), but the 
Table 1. Overview and general characterization of the evaluated cases from Spain and Portugal, including the level of participation, the participatory methods used, and the number of respondents.

\begin{tabular}{|c|c|c|c|c|c|c|}
\hline \multirow[t]{2}{*}{ Case name } & \multicolumn{3}{|c|}{ Level of participation } & \multirow[t]{2}{*}{ Participation methods } & \multirow[t]{2}{*}{ Period } & \multirow{2}{*}{$\begin{array}{l}\text { No. of } \\
\text { respondents }\end{array}$} \\
\hline & Pretty (1995) & $\begin{array}{l}\text { Rowe and Frewer } \\
(2000)\end{array}$ & Fung (2006) & & & \\
\hline \multicolumn{7}{|l|}{ Spain $^{\dagger}$} \\
\hline RDP I & $\begin{array}{l}\text { Passive } \\
\text { participation }\end{array}$ & Communication & $\begin{array}{l}\text { Who? } \\
\text { Expert administrators } \\
\text { How? } \\
\text { Technical expertise } \\
\text { Policy link? } \\
\text { Direct authority }\end{array}$ & $\begin{array}{l}\text { Communication by regional } \\
\text { government }\end{array}$ & 1999-2001 & 5 \\
\hline SoCo & $\begin{array}{l}\text { Participation by } \\
\text { consultation }\end{array}$ & Consultation & $\begin{array}{l}\text { Who? } \\
\text { Targeted recruiting } \\
\text { How? } \\
\text { Express preferences } \\
\text { Policy link? } \\
\text { Advise and consult }\end{array}$ & $\begin{array}{l}\text { Questionnaires, interviews, } \\
\text { workshop }\end{array}$ & $2007-2008$ & 4 \\
\hline RDP II & $\begin{array}{l}\text { Functional } \\
\text { participation }\end{array}$ & Participation & $\begin{array}{l}\text { Who? } \\
\text { Targeted recruiting } \\
\text { How? } \\
\text { Technical expertise } \\
\text { Policy link? } \\
\text { Advise and consult }\end{array}$ & $\begin{array}{l}\text { Focus groups, meetings, } \\
\text { communication by regional } \\
\text { government }\end{array}$ & 2006-2007 & 5 \\
\hline $\begin{array}{l}\text { DESERTLI- } \\
\text { NKS }\end{array}$ & $\begin{array}{l}\text { Interactive } \\
\text { participation }\end{array}$ & Participation & $\begin{array}{l}\text { Who? } \\
\text { Targeted recruiting } \\
\text { How? } \\
\text { Develop preferences } \\
\text { Policy link? } \\
\text { Communicative influence }\end{array}$ & $\begin{array}{l}\text { Stakeholder meetings, } \\
\text { questionnaires }\end{array}$ & 2002-2004 & 4 \\
\hline MEDACTION & $\begin{array}{l}\text { Interactive } \\
\text { participation }\end{array}$ & Participation & $\begin{array}{l}\text { Who? } \\
\text { Self-selection } \\
\text { How? } \\
\text { Aggregate and bargain } \\
\text { Policy link? } \\
\text { Communicative influence }\end{array}$ & $\begin{array}{l}\text { Stakeholder workshops for } \\
\text { scenario building, questionnaires }\end{array}$ & $2002-2004$ & 5 \\
\hline DESIRE & $\begin{array}{l}\text { Interactive } \\
\text { participation }\end{array}$ & Participation & $\begin{array}{l}\text { Who? } \\
\text { Self-selection } \\
\text { How? } \\
\text { Deliberation-negotiation } \\
\text { Policy link? } \\
\text { Communicative influence }\end{array}$ & $\begin{array}{l}\text { Questionnaires, interviews, } \\
\text { stakeholder workshops, field } \\
\text { demonstrations, newsletters }\end{array}$ & $2007-2011$ & 5 \\
\hline \multicolumn{7}{|l|}{ Portugal $^{\ddagger}$} \\
\hline MEDACTION & $\begin{array}{l}\text { Participation by } \\
\text { consultation }\end{array}$ & Consultation & $\begin{array}{l}\text { Who? } \\
\text { Targeted-recruiting } \\
\text { How? } \\
\text { Express preferences } \\
\text { Policy link? } \\
\text { Communicative influence }\end{array}$ & $\begin{array}{l}\text { Stakeholder meetings, } \\
\text { questionnaires }\end{array}$ & $2002-2004$ & 2 \\
\hline $\begin{array}{l}\text { DESERTLI- } \\
\text { NKS }\end{array}$ & $\begin{array}{l}\text { Interactive } \\
\text { participation }\end{array}$ & Participation & $\begin{array}{l}\text { Who? } \\
\text { Targeted-recruiting } \\
\text { How? } \\
\text { Develop preferences } \\
\text { Policy link? } \\
\text { Communicative influence }\end{array}$ & $\begin{array}{l}\text { Stakeholder workshops, } \\
\text { questionnaires. }\end{array}$ & $2002-2004$ & 5 \\
\hline RAA & $\begin{array}{l}\text { Functional } \\
\text { participation }\end{array}$ & Participation & $\begin{array}{l}\text { Who? } \\
\text { Professional stakeholders } \\
\text { How? } \\
\text { Deliberation-negotiation } \\
\text { Policy link? } \\
\text { Advise and consult }\end{array}$ & $\begin{array}{l}\text { Field surveys, stakeholder } \\
\text { workshops, training sessions }\end{array}$ & $2005-2010$ & 5 \\
\hline DESIRE & $\begin{array}{l}\text { Interactive } \\
\text { participation }\end{array}$ & Participation & $\begin{array}{l}\text { Who? } \\
\text { Self-selection } \\
\text { How? } \\
\text { Deliberation-negotiation } \\
\text { Policy link? } \\
\text { Communicative influence }\end{array}$ & $\begin{array}{l}\text { Field surveys, questionnaires, } \\
\text { interviews, stakeholder } \\
\text { workshops, newsletters }\end{array}$ & $2007-2011$ & 5 \\
\hline
\end{tabular}




\begin{tabular}{lll} 
MINDELO Self-mobilization Participation & Who? & Field survey, workshops, public 2003-2005 meetings \\
& Diffuse public sphere? & How? \\
& Deliberation-negotiation & Policy link? \\
& Cogovernance & \\
\hline
\end{tabular}

\footnotetext{
${ }^{\dagger}$ The Spanish case studies were located in semiarid to dry subhumid southeastern Spain and dealt with the selection of sustainable land management solutions to problems of land degradation, desertification, and water shortage.

* Four of the Portuguese cases focused on preventing and restoring land from forest fires, while the fifth case was developed at Mindelo village, located in northern Portugal, where a local Agenda 21 initiative developed an action plan for the sustainable development and environmental conservation of a dry subhumid natural area.
}

contexts in which the process was carried out differed much more markedly than in the Spanish and Portuguese cases. Such variation between sites included socio-cultural, political, economic, and environmental differences, as well as variation in types of land degradation experienced. Projects in each site tackled issues ranging from salinity in Russia to overgrazing in Botswana. Evidence from the DESIRE cases was based on analysis of interviews with the participatory process facilitators in each site.

Table 2. DESIRE study sites and the main land degradation problem considered (see also Figure 1).

\begin{tabular}{|c|c|}
\hline DESIRE study site & Main land degradation problem \\
\hline 1. Boteti area (Botswana) & Overgrazing \\
\hline 2. Santiago Island (Cape Verde) & $\begin{array}{l}\text { Soil erosion by water and climate } \\
\text { variability }\end{array}$ \\
\hline 3. Cointzio catchment (Mexico) & Soil erosion by water \\
\hline 4. Crete (Greece) & $\begin{array}{l}\text { Soil erosion by water, overgrazing, } \\
\text { water stress }\end{array}$ \\
\hline 5. Djanybek (Russia) & Water shortage and salinization \\
\hline 6. Eskisehir (Turkey) & Soil erosion by water \\
\hline 7. Góis and Mação (Portugal) & Forest fires \\
\hline 8. Guadalentín basin (Spain) & $\begin{array}{l}\text { Soil erosion by water and water } \\
\text { shortage }\end{array}$ \\
\hline 9. Karapinar plain (Turkey) & Wind erosion \\
\hline 10. Loess Plateau (China) & Soil erosion by water and wind \\
\hline 11. Mamora/Sehoul (Morocco) & $\begin{array}{l}\text { Soil erosion by water and } \\
\text { overgrazing }\end{array}$ \\
\hline 12. Novij Saratov (Russia) & Water shortage and salinization \\
\hline 13. Secano Interior (Chile) & $\begin{array}{l}\text { Soil erosion by water and extensive } \\
\text { gullying }\end{array}$ \\
\hline
\end{tabular}

To obtain a more comprehensive view and represent differences in perception, we interviewed people playing a variety of roles in participatory projects in Spain and Portugal, including facilitators, researchers, and a representative range of process participants, e.g., land owners, representatives of farmers' organizations, local and regional governments. In Spain, we interviewed 18 people across 6 projects. Several respondents participated in more than 1 project and for 2 projects (DESERTLINKS and SoCo) we found only 4 respondents willing to be interviewed. For the Portuguese cases we conducted 22 interviews. We found only 2 participants of MEDACTION to be interviewed and 1 of them answered only the open questions (Valente 2013). For the 13 DESIRE cases, we interviewed only the process facilitator from each study site, giving a sample size of 13 full interviews.
Fig. 1. Location and global coverage of the 13 evaluated DESIRE study sites (world image obtained from MODIS Earth-composite).

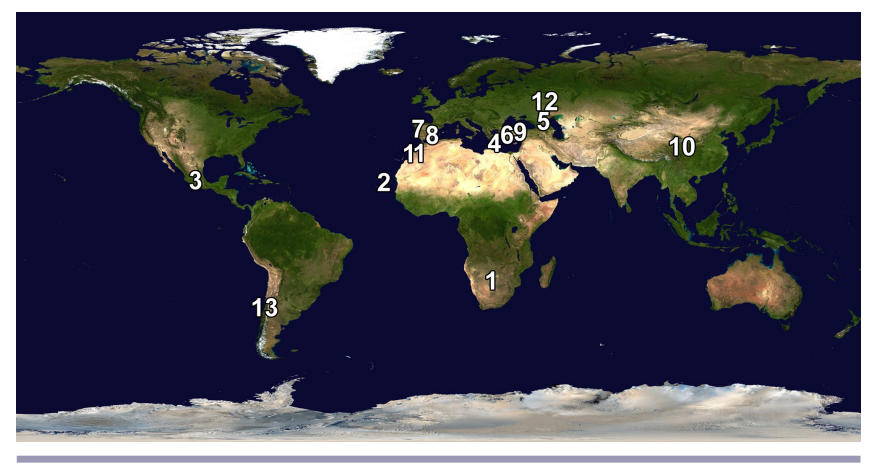

Quantitative and qualitative analysis

We used a combined quantitative and qualitative approach to evaluate all cases using a questionnaire consisting of two parts. The first part comprised five open questions around which discussion took place as part of a semistructured interview. These questions asked respondents to identify the most important outcomes of participation, factors leading to the successful achievement of these outcomes, a description of their project, and the main challenges for participation that they faced. The second (structured) part contained 51 closed questions, where we asked respondents to provide an integer score between 0 and 4 or between -4 and 4, during the same interview (see Appendix 1). Questions addressed issues related to context, process design, the actual process, and process outcomes. Questions about context referred to aspects like the existing policy, legal and institutional framework, social networks, trust between stakeholder groups, and the type of environmental problem under consideration. Questions about process design referred to characteristics such as who initiated and facilitated the process, who participated, and how knowledge exchange and decision making were facilitated. The second part of the questionnaire was based on the "Scheme for the Comparative Analysis of Public Environmental decisionmaking" (SCAPE) prepared as part of a larger research project that aims to assess if participatory governance improves environmental policy delivery, drawing on a meta-analysis of 250 published case studies (Newig et al. 2013). We transcribed the answers to the open questions and used grounded theory analysis to identify the main outcomes and challenges of participation and to highlight the key principles of best practice in a 
Table 3. Spearman correlations between process design variables and process outcomes for the 11 Spanish and Portuguese cases (only correlations with $\mathrm{p}<0.01$ are shown). See methods section and questionnaire in annex for detailed description of process design and outcome variables.

\begin{tabular}{|c|c|c|c|c|c|c|c|c|c|c|c|c|c|c|c|}
\hline \multirow[b]{2}{*}{ Process design parameters } & \multicolumn{15}{|c|}{ Output parameters (key below) } \\
\hline & 1 & 2 & 3 & 4 & 5 & 6 & 7 & 8 & 9 & 10 & 11 & 12 & 13 & 14 & 15 \\
\hline Involvement of leaders & & 0.54 & 0.42 & & 0.51 & 0.55 & & & 0.48 & & & 0.41 & & & \\
\hline Involvement of implementers & & 0.52 & 0.53 & & 0.51 & 0.51 & & & 0.51 & & 0.43 & & & & \\
\hline Legitimate representation & 0.50 & 0.47 & 0.54 & & 0.52 & 0.54 & & & 0.50 & & 0.38 & & 0.45 & 0.40 & \\
\hline Nonstate actor influence & 0.45 & 0.64 & 0.42 & & & & & & 0.53 & & 0.43 & & & & \\
\hline Communication to nonstate actors & 0.40 & 0.46 & 0.53 & 0.40 & & & & & 0.39 & 0.39 & & 0.46 & 0.45 & & \\
\hline $\begin{array}{l}\text { Information exchange through face-to- } \\
\text { face contact }\end{array}$ & & 0.55 & 0.45 & 0.40 & 0.43 & 0.50 & & & 0.67 & 0.40 & & & 0.54 & & \\
\hline Deliberation with equal opportunities & & 0.52 & 0.50 & 0.49 & 0.40 & 0.48 & & & 0.68 & 0.56 & 0.55 & 0.47 & 0.68 & 0.54 & \\
\hline Discursive fairness to all participants & 0.38 & 0.52 & 0.47 & & 0.46 & 0.56 & & & 0.72 & 0.53 & 0.41 & 0.44 & 0.63 & 0.46 & \\
\hline Participation rationale: empowerment & & & 0.42 & & & & & & & & & & 0.51 & & \\
\hline $\begin{array}{l}\text { Participation rationale: democratic } \\
\text { legitimacy }\end{array}$ & & & 0.49 & & & & & & 0.46 & 0.54 & 0.43 & 0.57 & 0.65 & & \\
\hline $\begin{array}{l}\text { Participation rationale: environmental } \\
\text { benefits }\end{array}$ & & & & & & & & & & 0.39 & 0.39 & 0.47 & 0.40 & 0.49 & \\
\hline Competent authority as initiator & -0.56 & -0.49 & -0.47 & -0.43 & & & & & -0.67 & & & & -0.55 & & 0.47 \\
\hline Competent authority as participant & & & & & & & 0.41 & 0.56 & & & & & & & 0.40 \\
\hline $\begin{array}{l}\text { Competent authority as mediator/ } \\
\text { facilitator }\end{array}$ & -0.42 & & & -0.52 & & & 0.42 & 0.52 & & -0.52 & & & -0.49 & & \\
\hline Controlled participant selection & & -0.44 & -0.48 & & & -0.45 & & & -0.58 & & & & -0.41 & & \\
\hline Previous stakeholder analysis & 0.55 & & & & & & & & 0.44 & 0.47 & 0.49 & & 0.44 & & \\
\hline $\begin{array}{l}\text { Facilitated knowledge exchange (e.g., } \\
\text { workshops) }\end{array}$ & 0.48 & & & & & 0.56 & & & 0.72 & 0.61 & 0.57 & 0.48 & 0.62 & & \\
\hline $\begin{array}{l}\text { Structured information aggregation (e.g., } \\
\text { voting) }\end{array}$ & 0.45 & 0.46 & & & & 0.46 & & & 0.65 & 0.49 & 0.42 & & 0.56 & & \\
\hline Process moderation/facilitation & 0.49 & 0.44 & & & & 0.45 & & & 0.72 & 0.51 & 0.44 & & 0.53 & & \\
\hline
\end{tabular}

1: Information gain; 2: Mutual gains; 3: Attainment of initial goals compared to final decision; 4: Flexible solutions adaptive to new knowledge; 5: Sustainable solutions; 6: Conflict resolution; 7: Acceptance by those who have to implement and apply solutions; 8 : Acceptance by the competent authority; 9: Learning by participants; 10: Trust among nonstate actors; 11: Trust between nonstate actors and competent authority; 12: Trust between competent authority and scientists; 13: Trust between nonstate actors and scientists; 14: Socially equitable output; 15: Implementation of solutions.

participatory process. Grounded theory analysis is a qualitative method used to systematically analyze large bodies of text, to construct theoretical models that are grounded in the text (Corbin and Strauss 1990), or in our case, the interviewees' responses to our questions. Using the answers from the second part of the questionnaire, we explored significant statistical correlations ( $p$ $<0.01$ ) between process design, context parameters, and process outcomes, based on nonparametric Spearman correlation coefficients calculated in SAS statistical software (SAS 2011). We used the combined results from the quantitative and qualitative assessment to support the discussion, conclusions, and recommendations for the design of participatory processes.

\section{RESULTS}

The role of process design: findings from the analysis of participatory processes in Spain and Portugal

Statistical analysis of answers to structured interviews with people engaged in processes with varying levels of participation in Spain and Portugal showed that $73 \%$ of the evaluated process design variables significantly affected at least one of the perceived outcomes $(p<0.01)$. Seventy-eight percent of the outcomes significantly correlated to at least one process design variable. Despite potential differences in perception between people involved in the processes, we found no significant differences between outcomes perceived by facilitators and other participants. We did find significant correlations between various process design variables and process outcomes, meaning that respondents' perceptions were not diverse. Table 3 shows all significant correlations $(\mathrm{p}<0.01)$ between process design variables and process outcomes, which are summarized below:

- Legitimate representation of stakeholders, including opinion leaders and those who would need to implement decisions, significantly increased the likelihood of learning among participants; development of mutual gains and sustainable solutions that addressed socioeconomic and environmental concerns; and attaining the goals specified at the start of the process;

- Conversely, where those who initiated the process controlled participant selection, mutual gains and win-win solutions were less likely; the process was less likely to reach its originally stated goals; conflict resolution was less likely; participants were less likely to learn from each other; and the process was less likely to foster trust between nonstate actors and researchers;

- Processes preceded by a stakeholder analysis were significantly more likely to lead to information gain and learning among participants and enhanced trust among different stakeholders who did not represent the government ("nonstate actors"), between nonstate actors and the 
governmental institution responsible for the decisionmaking process, and between nonstate actors and researchers.

- Professionally facilitated processes that included structured methods for eliciting and aggregating information from participants, e.g., sorting and prioritization methods, were more likely to lead to information gain and learning among participants; win-win solutions; conflict resolution; and enhanced trust among nonstate actors, between nonstate actors and the governmental institution responsible for the decision-making process, and between nonstate actors and researchers;

- In processes where nonstate actors received relevant information as part of the process and were able to have a significant influence on decision making within the process there was a significant likelihood that participants would gain information and learn from each other; win-win solutions would be reached; and the original goals of the process would be reached;

- If information exchange occurred through face-to-face contact between participants, there was also a significantly greater likelihood that the process would lead to sustainable solutions; conflict resolution; increased trust among nonstate actors and between nonstate actors and researchers;

- In processes where all participants could freely make statements and participate in discussion and decision making, the process would lead to win-win and sustainable solutions that are deemed to be socially equitable; achieve its original goals; contribute toward conflict resolution; facilitate learning between participants; and increase trust among all participant groups;

- Participatory processes that were initiated with the goal of empowering stakeholders were highly likely to achieve their stated goals, while processes initiated to achieve specific environmental outcomes or that had an underlying rationale of providing democratic legitimacy to decisions were associated with beneficial social outcomes, in particular, increased trust among participants;

- Participatory processes initiated and/or facilitated by government bodies were less likely to lead to information gain, learning by participants, flexible solutions that could adapt to new knowledge, or to contribute toward trust between nonstate actors and researchers. However, in these processes or those where government bodies were present as participants, the decisions that emerged were more likely to be accepted by the government and by those who had to implement them on the ground, and decisions were more likely to be implemented.

We further explored these relationships between process design variables and process outcomes identified through quantitative analysis by means of qualitative analysis of answers to open questions. The qualitative analysis echoed many of the findings from the quantitative analysis while also providing additional insights. For example, many respondents mentioned the importance of selecting relevant participants in relation to the process objectives (Box 2). Where the aim of a participatory process was to create scenarios or develop innovative ideas, respondents emphasized the importance of involving civil servants, researchers, land owners, and technicians. If these scenarios or ideas were intended to have an impact on policy, then more strategic stakeholders like farmers' organizations and highlevel policy makers needed to take part and commit themselves to the process.

\section{Box 2:}

Illustrative quotes concerning the impact of process design on process outcomes

"If you want to have an impact, for example, organize a 1-day workshop, because you want the higher level policy makers, who will not come for more than 1 day." [Scientist, Spanish case]

"A very important aspect is the presence of influential people at the meeting, able to raise synergies during the meeting. Recognized farmers, the mayor, well, persons that have influence over others, over the community." [Scientist, Portuguese case]

"It is important to guarantee the representativeness of the stakeholders, from different entities and with different roles." [Local CSO, Portuguese case]

Respondents further argued that policy makers with decisionmaking power needed to be included in the process for short-term implementation and impact because they have the means to implement decisions in policy and provide incentives for their wider scale implementation. However, the power imbalance could limit active participation and the emergence of new ideas from other participants. To foster trust, the language, form, and location of communication must be adapted to each stakeholder group. Respondents reported that field visits or village meetings were often more effective than seminar presentations at Universities or government buildings. By using the local knowledge of those directly dependent on the threatened resources, participation led to solutions that fitted local conditions and were therefore more effective than top-down decisions. Most respondents also stressed that social and political change processes take time. Therefore, successful participation requires long-term commitment from all participants.

\section{The impact of minor variations in local context on process outcomes: findings from participatory processes in Spain and Portugal}

Table 4 shows all significant correlations $(p<0.01)$ between local context variables and perceived process outcomes in the Spanish and Portuguese cases. Twenty-six percent of the context parameters were significantly associated with at least one of the perceived outcomes of participation. Thirty-seven percent of the outcomes significantly correlated to at least one context variable. These findings are summarized as follows:

- Participatory processes taking place in an autocratic institutional culture, with little decision making autonomy for individuals, are less likely to result in socially equitable outcomes; 
Table 4. Spearman correlations between context variables and process outcomes for the 11 Spanish and Portuguese cases (only correlations with $\mathrm{p}<0.01$ are shown). See methods section and questionnaire in annex for detailed description of context and process outcome variables.

\begin{tabular}{|c|c|c|c|c|c|c|c|}
\hline \multirow[b]{2}{*}{ Context variables } & \multicolumn{7}{|c|}{ Output parameters } \\
\hline & $\begin{array}{c}\text { Mutual } \\
\text { gains }\end{array}$ & $\begin{array}{c}\text { Flexible } \\
\text { solutions } \\
\text { adaptive to new } \\
\text { knowledge }\end{array}$ & $\begin{array}{c}\text { Sustainable } \\
\text { solutions }\end{array}$ & $\begin{array}{l}\text { Acceptance } \\
\text { by the } \\
\text { competent } \\
\text { authority }\end{array}$ & $\begin{array}{c}\text { Trust between } \\
\text { nonstate } \\
\text { actors and } \\
\text { competent } \\
\text { authority }\end{array}$ & $\begin{array}{c}\text { Trust } \\
\text { between } \\
\text { nonstate } \\
\text { actors and } \\
\text { scientists }\end{array}$ & $\begin{array}{c}\text { Socially } \\
\text { equitable } \\
\text { output }\end{array}$ \\
\hline Existence of previous policy & & & -0.36 & & & & \\
\hline Decision making autonomy & & & & & & & 0.33 \\
\hline Power imbalance & -0.38 & & & & & & \\
\hline Agenda setter: nonstate actors & & & & & 0.35 & & 0.32 \\
\hline Cooperating private enterprises & & & 0.52 & 0.41 & & & \\
\hline Cooperating civil society organizations & 0.32 & 0.41 & & & & & \\
\hline $\begin{array}{l}\text { Problem understanding by civil society } \\
\text { organizations }\end{array}$ & & & & & & 0.32 & \\
\hline Cooperating individuals & 0.38 & & & & & & \\
\hline
\end{tabular}

- Power imbalances among participants significantly reduce the likelihood of mutual gains and win-win solutions;

- Participatory processes initiated in response to an agenda set by nonstate actors are more likely to lead to socially equitable outcomes and enhance trust between nonstate actors and the competent authority, i.e., the governmental institution responsible for decisions arising from the process;

- Processes with strong cooperation from private enterprises are more likely to lead to solutions that are accepted by government bodies and deemed sustainable, addressing socioeconomic as well as environmental concerns. However, solutions to a problem were significantly less likely to be deemed sustainable when policy regulating the problem under consideration already existed;

- Strong cooperation from civil society organizations and landowners and managers was likely to lead to mutual gains and win-win solutions regarding economic and conservation objectives. In addition, cooperation from civil society organizations correlated positively with the delivery of solutions that are flexible and able to adapt to new knowledge as it becomes available;

- Implementation of outputs identified during participatory processes was not strongly associated with any contextual parameters. We found weaker associations $(\mathrm{p}<0.05$, not indicated in Table 4) between implementation of solutions and a good understanding of the environmental problem by individuals participating in the process, a government that cooperates in the process, trust among nonstate actors, and trust between nonstate actors and the competent authority.

Qualitative interview analysis provided more detailed insights into the role of local context (Box 3). Most respondents stressed the importance of personal motivation of stakeholders to participate and the sense that their contributions will be acted upon. This in turn often related to available funding and the extent to which a process could feed directly into policy. Motivation to participate was strongly reduced if there was no funding for implementation of solutions, or if participation was merely a minor part of a research project. These challenges may be exacerbated because environmental problems like land degradation are often gradual or intangible processes, so many stakeholders do not give them priority.

\section{Box 3:}

Illustrative quotes concerning the impact of local context on process outcomes

"People often complain to me: Why do you ask my opinion, if you will do whatever you want after all? How will I know my opinion is reflected in the final decision?" [Local government representative, Spanish case].

"If you ask farmers about their main environmental concerns, land degradation will certainly not be on top of their list" [local government representative, Spanish case].

"Portuguese do not have much tradition of participation; we have some examples of laws stating that people should get involved through participation, but in fact they did not work as such" [Scientist, Portuguese case ].

"It is the competent authority that determines if there is or is not effective participation, and if they include the contribution of public participation in the decision-making processes or not" [Scientist, Portuguese case].

\section{The role of national context parameters: findings from an international process}

Table 5 lists the mean scores of process outcomes as ranked by interviewees from the 13 DESIRE cases. These showed great similarity with the top eight outcomes identified by interviewees from the Spanish and Portuguese cases (see footnote Table 5). There was considerable overlap between the top ranked outcomes for the majority of DESIRE cases, despite the participatory process being conducted in very different national contexts. The 
Table 5. Ranking outputs from 13 DESIRE cases indicating mean and standard deviations of 13 scores. High scores refer to a higher importance of that output. Negative scores refer to a negative or decreased output.

\begin{tabular}{|c|c|c|}
\hline Process outcome & $\begin{array}{c}\text { Average score (possible } \\
\text { range) }\end{array}$ & Standard deviation \\
\hline Information gain to make more informed decisions $^{\dagger}$ & $3.3(0$ to 4$)$ & 0.8 \\
\hline Sustainable solutions (i.e., social, economic, environmental interests) ${ }^{\dagger}$ & $3.2(0$ to 4$)$ & 0.7 \\
\hline Acceptance by participants & $3.2(0$ to 4$)$ & 0.8 \\
\hline Learning by participants ${ }^{\dagger}$ & $3.1(0$ to 4$)$ & 0.6 \\
\hline Flexible solutions adaptive to new knowledge ${ }^{\dagger}$ & $2.9(0$ to 4$)$ & 0.9 \\
\hline Acceptance by those who have to implement and apply solutions ${ }^{\dagger}$ & $2.9(0$ to 4$)$ & 0.8 \\
\hline Mutual gains and win-win solutions ${ }^{\dagger}$ & $2.8(0$ to 4$)$ & 0.9 \\
\hline Trust between nonstate actors and scientists & $2.7(-4$ to 4$)$ & 1.1 \\
\hline Economically rational output & $2.5(-4$ to 4$)$ & 1.0 \\
\hline Feasible solutions (i.e., monitoring, control, and sanction potential) ${ }^{\dagger}$ & $2.5(0$ to 4$)$ & 0.9 \\
\hline Actual implementation of solutions & $2.5(0$ to 4$)$ & 0.8 \\
\hline Acceptance by the competent authority & $2.3(0$ to 4$)$ & 1.3 \\
\hline Socially equitable output & $2.1(-4$ to 4$)$ & 1.4 \\
\hline Trust among nonstate actors & $1.9(-4$ to 4$)$ & 1.3 \\
\hline Attainment of initial goals compared to final decision & $1.7(-4$ to 4$)$ & 1.3 \\
\hline Trust between nonstate actors and competent authority & $1.6(-4$ to 4$)$ & 1.3 \\
\hline Conflict resolution & $0.9(-4$ to 4$)$ & 1.0 \\
\hline
\end{tabular}

${ }^{\dagger}$ Among the top eight outcomes identified by interviewees from the Spanish and Portuguese cases.

four most important perceived outcomes from the DESIRE cases (average score above 3) were: (i) information gain, (ii) identification of sustainable solutions, (iii) acceptance of solutions, and (iv) learning by participants. Most interviewees also reported increased trust among participants and the development of economically rational and socially equitable solutions as important outcomes. Similar themes emerged from the qualitative analysis of interview transcripts. Table 6 identifies five broad types of outcomes that emerged from this qualitative analysis for all 13 DESIRE cases.

As outcomes of the participatory process were similar across all sites, despite the large contextual variations, it appears that national context had little influence on outcomes. This is not to say that context had no effect on outcomes whatsoever. The limited amount of variation in outcomes could be explained by a small proportion of the contextual factors $(13 \%)$ that were significantly $(\mathrm{p}<0.01)$ correlated with $21 \%$ of the outcome variables (Table 7 ), specifically the following:

- In three specific types of context, participants were more likely to gain information from their participation in the participatory process (i) if the issues being discussed had been proposed by the competent authority, i.e., the governmental institution responsible for the issue; (ii) if the issue had been put on the agenda as a result of a previous government policy; or (iii) if the issues being dealt with in the process related to nature conservation, as opposed to other issues such as health or the exploitation of scarce natural resources.

- If the issues being tackled had previously received media attention, then the DESIRE participatory process was more likely to enhance trust between (i) government representatives, i.e., state actors, and other stakeholders, i.e., nonstate actors; (ii) nonstate actors and researchers involved in the process; and (iii) between different nonstate actors involved in the process.
Further national contextual factors emerged during the qualitative analysis of interview transcripts. The most important factors that negatively affected the outcomes of the DESIRE process were apathy of stakeholders toward participation in some countries, previous negative experiences with participation, or because power imbalances reduced engagement.

\section{DISCUSSION}

\section{Environmental and social outcomes of well-designed participatory processes}

Those who argue the case for participation do so primarily for normative, pragmatic, or instrumental reasons (Chambers 1983, Fiorino 1990, Reed 2008). In our study, all interviewees emphasized pragmatic benefits of participation, for example, arriving at decisions that are better informed and feasible. They also noted decisions were more durable and flexible and observed a higher level of acceptance and ownership of decisions by participants and decision makers. Our findings support literature claiming that participation can enable groups to go beyond the acquisition of factual knowledge, to collectively and creatively develop new solutions through genuine deliberation and reflection, an inspiring group atmosphere, and the multiplicity of perspectives involved (Pahl-Wostl and Hare 2004, Siebenhüner and Suplie 2005). Overall, our research confirms that well designed participatory processes are likely to lead to more beneficial environmental outcomes through better informed, sustainable decisions, and win-win solutions regarding economic and conservation objectives.

We did not find a direct link between most process design characteristics and acceptance or implementation of solutions. However, the use of professional facilitation and structured methods of knowledge aggregation during participatory processes correlated positively with social outcomes, including information gain, conflict resolution, learning, and trust among stakeholder groups. At the same time, transparency and trust, 
Table 6. Outcomes from the participatory process conducted as part of the DESIRE project across 13 study sites internationally, including a description of the outcome and a representative quote (from qualitative interview analysis).

\begin{tabular}{|c|c|c|}
\hline Outcome & Description & Example Quote \\
\hline $\begin{array}{l}\text { Enhanced social networks, } \\
\text { collaboration, and trust among } \\
\text { participants }\end{array}$ & $\begin{array}{l}\text { Most interviewees mentioned that participation builds and strengthens } \\
\text { relationships between individuals and organizations leading to new } \\
\text { collaborations, both within and outside the participatory process. } \\
\text { Successful processes were felt to increase trust between land users and } \\
\text { institutional participants. }\end{array}$ & $\begin{array}{l}\text { "For the stakeholders this kind of } \\
\text { experiences is very useful, because it } \\
\text { develops contacts and further collaboration } \\
\text { among the stakeholders." [Facilitator, } \\
\text { Portugal] }\end{array}$ \\
\hline $\begin{array}{l}\text { Learning and knowledge } \\
\text { exchange among participants }\end{array}$ & $\begin{array}{l}\text { Participatory processes provide a forum for discussion among } \\
\text { stakeholders that otherwise do not often meet or may find it difficult to } \\
\text { communicate with one another. By learning from each other during the } \\
\text { process, it may be possible to better appreciate the motives and rationale } \\
\text { behind the attitudes and behaviour of different participants. By sharing } \\
\text { knowledge with each other, it may be possible to identify and critique } \\
\text { new solutions to land management challenges. }\end{array}$ & $\begin{array}{l}\text { "Before we could not understand why } \\
\text { farmers don't apply certain technologies. } \\
\text { Participation allows us to learn from the } \\
\text { stakeholders about the limitations and } \\
\text { problems." [Facilitator, Chile] }\end{array}$ \\
\hline $\begin{array}{l}\text { Better problem identification and } \\
\text { awareness }\end{array}$ & $\begin{array}{l}\text { Stakeholders start thinking more holistically by identifying direct and } \\
\text { indirect effects of their actions. Interaction between researchers and } \\
\text { other stakeholders can force researchers to question the assumptions } \\
\text { that underlie their work and lead to more rigorous research. }\end{array}$ & $\begin{array}{l}\text { "Participation makes people think about } \\
\text { the problem as a whole." [Facilitator, } \\
\text { China] }\end{array}$ \\
\hline $\begin{array}{l}\text { Consensus, acceptance, and } \\
\text { implementation of tailor-made } \\
\text { solutions is more likely }\end{array}$ & $\begin{array}{l}\text { Participants are more likely to reach consensus over, or accept a group } \\
\text { decision by deliberating together over its likely impacts. As people feel } \\
\text { increased ownership over the problem and the solutions that have been } \\
\text { identified, they are more motivated to actually implement agreed } \\
\text { solutions. This may be further enhanced by observing proposed } \\
\text { solutions during field demonstrations. By combining the expertise of } \\
\text { researchers and local communities in the decision-making process, } \\
\text { solutions are tailor-made to the local context. }\end{array}$ & $\begin{array}{l}\text { "Even if people do not agree at the } \\
\text { beginning, they can accept change if they } \\
\text { can see the benefits." [Facilitator, Morocco] }\end{array}$ \\
\hline $\begin{array}{l}\text { More confident and motivated } \\
\text { stakeholders }\end{array}$ & $\begin{array}{l}\text { Participants gain confidence as they feel that their views are taken } \\
\text { seriously in the participatory process. This makes them feel that their } \\
\text { participation in the decision-making process really does make a } \\
\text { difference, and they are more likely to actively engage in it. Local land } \\
\text { users and groups that are otherwise often not heard are given a voice } \\
\text { through participation. }\end{array}$ & $\begin{array}{l}\text { "It was the first time the experts and } \\
\text { farmers came together to discuss their own } \\
\text { problems. It helped give the farmers more } \\
\text { self-esteem." [Facilitator, Turkey] }\end{array}$ \\
\hline
\end{tabular}

especially between land users and government bodies, are needed to make these structured forms of participation successful. This is consistent with other studies that have identified mutual trust among the participants as both a precondition for social learning (Wenger 2000, Leach and Sabatier 2005) and an outcome of social learning in participatory processes (Pahl-Wostl et al. 2007). Our results further show that participation provides opportunities for participants to get to know each other and each other's concerns. This increases trust and development of alliances and other networks. Outcomes from decision-making processes that are perceived as fair and legitimate are more likely to be accepted by stakeholders over the long term (Lind and Tyler 1988, Young et al. 2013).

Increased trust and learning were perceived as major outcomes of participation. The reason for this may be that participatory processes tend to seek and value a range of perspectives, leading to the appreciation of different stakeholder positions. By enabling participants to listen to a wider range of perspectives with less prejudice, participation may enable learning at a number of levels: from better understanding the decision on a cognitive level, to deeper learning that can enable participants to re-evaluate the assumptions and values underlying their positions. This can foster changes in attitudes that shift their positions so that they are more in line with their values in relation to the environment (Argyris and Schön 1978, Fazey et al. 2005, Keen and Mahanty 2006, Kenter et al. 2014). New understandings, attitudes, and positions that arise from this learning process may then diffuse from those directly participating in the process to those in their social network by social learning (Reed et al. 2010).

\section{How important is process design in determining the outcomes of} participatory processes?

Our research explicitly addresses many of the concerns in the literature about stakeholder participation in management of social-ecological systems. Interviews with those who facilitated or were engaged in participatory processes highlighted the dangers of poorly designed or implemented participatory processes. Respondents pointed specifically to inadequate representation of relevant stakeholders, and inattention to power dynamics. Without effective design and strong facilitation, more powerful individuals have the potential to limit the engagement of others and bias the outcomes.

Although acknowledging potential for failure, this research identifies factors that are most likely to lead to failure, and those aspects of process design that will reduce the risk of failure. Table 8 summarizes seven recommendations for the design of participatory processes in management of social-ecological systems, based on the evaluation of all interviews from all cases presented here, and relating them to their expected outcomes. These recommendations are not to be seen as individual tools, but as an integral approach required to achieve the indicated outcomes. They may be considered design considerations for participatory processes that always need to be enacted by practitioners in their given context. 
Table 7. Spearman correlations between context variables and main process outcomes for the 13 DESIRE cases (only correlations with $p<0.01$ are shown). See methods section and questionnaire in Appendix 1 for detailed description of context and process outcome variables.

\begin{tabular}{lccc}
\hline \hline & & Output parameters \\
\cline { 2 - 4 } Context parameters & Information gain & $\begin{array}{c}\text { Trust among } \\
\text { nonstate actors }\end{array}$ & $\begin{array}{c}\text { Trust between nonstate } \\
\text { actors and authority }\end{array}$ \\
\hline Agenda setter: previous policy & 0.76 & \\
Agenda setter: competent authority & 0.65 & 0.78 \\
Problem related to nature conservation & 0.62 & 0.76 \\
Public (media) attention for the problem & & 0.58 \\
\hline
\end{tabular}

In line with the literature (Newig and Fritsch $2009 a$, Reed et al. 2009, Stanghellini 2010), our results suggest that participant selection strongly determines the outcomes of a participatory process. Legitimate representation of stakeholders, including opinion leaders and implementers, facilitates learning and trust among participants, leading to selection of sustainable solutions and fulfilment of project objectives. Respondents stressed the importance of performing a stakeholder analysis to identify key players and assist participant selection. However, too restrictive, controlled participant selection may deliver fewer positive social outcomes, i.e., less learning, conflict resolution, and trust building, and may increase conflict. Indeed, Reed et al. (2009) warn against the use of stakeholder analysis to marginalize less influential stakeholders. Careful selection of participants is needed to guarantee a heterogeneous group of people who represent all stakeholders' interests, including those with high levels of interest and low levels of influence in the decision, as well as strategic stakeholders with power, motivation, and means to implement decisions. Our findings suggest that to increase acceptance and implementation of solutions, governmental institutions responsible for the decision-making process and those who have to implement the solutions, such as land owners and managers, should be involved early in the decision-making process because this will give them ownership and greater acceptance of selected solutions (cf. Stringer and Dougill 2013).

Our respondents stressed that a diverse group of well-informed stakeholders will provide most comprehensive and innovative ideas. However, this is not simply about providing more comprehensive information inputs to the decision-making process. Information gain, learning, selection of sustainable solutions, and actual implementation of solutions depend on the group composition, the process design, and equal opportunities to start or participate in discourse. A diverse group of civil servants, land owners, researchers, and technicians is likely to provide sustainable and flexible solutions that are responsive to new knowledge, but these are not necessarily accepted and implemented by government bodies or those responsible for implementation. Processes where government bodies act as participants or facilitators provided fewer social outcomes, that is, less information gain, learning, and trust among stakeholder groups, and less flexible solutions, most likely because of a perceived power imbalance. However, these processes resulted in better acceptance and actual implementation by those who have to implement solutions. This stresses the importance of process design and skilled facilitation in dealing with power relations and differences in background and education among stakeholders. This may also point toward the need for selection or grouping of participants according to the process objectives. These findings and especially the need for government involvement to achieve wider stakeholder acceptance are in line with results reported by Young et al. (2012) and Sandström et al. (2014).

Our respondents emphasized that to be effective, participation must be easy and attractive. This means it should be clear what is in it for participants and how their contributions will be acted upon. Participants must gain returns for their time investment, for example, knowledge, contacts, or influence on decision making. Therefore, respondents suggested that a clear description of the problem and of the process objectives is crucial, so that stakeholders easily identify with the problem, irrespective of their background or education level. For example, stakeholders will find it easier to identify with specific tangible aspects of land degradation, e.g., water shortage or reduced crop productivity, than with the relatively slow process of land degradation itself. Respondents further indicated that continuous participation in problem definition, identification, selection, implementation, and evaluation of solutions is preferred over ad hoc participation or lower levels of participation like consultation and communication. Decision making through dialogue, deliberation, and face-to-face contact is preferred because this increases trust and ownership over solutions. However, the level of participation may vary throughout the process, and to prevent unsatisfactory compromises, there may be need for cut-off points where someone has to make a decision, respecting but not necessarily fulfilling all stakeholder opinions. Communication and transparency of decisions are crucial in this phase to maintain trust and involvement. Irrespective of the level of participation, participants need to receive regular feedback on implementation of the outputs. Without this, stakeholder fatigue and distrust can ensue.

Where problematic relationships between individuals or organizations emerge during stakeholder analysis, it may be possible to design parallel processes through which trust can be built more slowly. Handing responsibility for running the process to an independent facilitator that is perceived to be neutral and trusted by participants can also be useful. Moreover, providing participants with sufficient independent background information, using structured forms of information aggregation, and adapting language and location to participants, will also increase trust and thereby acceptance and possible implementation of solutions. In line with Diduck and Sinclair (2002), a high likelihood of an actual impact on policy, e.g., evidence of buy-in to the process by high level policy makers, also increases stakeholders' motivation to participate. 
Table 8. Summary of recommendations for the design of participatory processes in environmental management to achieve more beneficial environmental and social outcomes.

\begin{tabular}{|c|c|c|}
\hline Recommendations & Description & Expected outcome \\
\hline 1. Select your participants carefully & $\begin{array}{l}\text { Perform a stakeholder analysis and select representative, } \\
\text { diverse stakeholders (incl. land owners, government } \\
\text { institutions, opinion leaders, innovators, private } \\
\text { companies, and CSO's), in relation to the process } \\
\text { objectives. }\end{array}$ & $\begin{array}{l}\text { Information gain } \\
\text { Learning } \\
\text { Mutual gains (win-win) } \\
\text { Sustainable solutions } \\
\text { Goal attainment } \\
\text { Increased trust } \\
\text { Increased acceptance }\end{array}$ \\
\hline 2. Make participation attractive and easy & $\begin{array}{l}\text { Participation must make a difference, so negotiate } \\
\text { ambitious, realistic objectives, aid problem ownership } \\
\text { and respect time constraints of participants, but take the } \\
\text { time needed to build relationships and think solutions } \\
\text { through. Establish collaboration with similar initiatives } \\
\text { and link the process to ongoing political processes to } \\
\text { ensure actual policy impact. }\end{array}$ & $\begin{array}{l}\text { Increased problem ownership and } \\
\text { participation } \\
\text { Increased trust }\end{array}$ \\
\hline 3. Foster trust among participants & $\begin{array}{l}\text { Build on existing relationships among participants by } \\
\text { using existing networks for communication. Attract } \\
\text { media attention about the problem and the process. A } \\
\text { minimum level of trust is required among participants at } \\
\text { the start of the process. Design parallel processes for } \\
\text { high-level policy makers. Respect the knowledge of all } \\
\text { participants critically evaluating both scientific and local } \\
\text { knowledge. }\end{array}$ & $\begin{array}{l}\text { Increased trust } \\
\text { Increased acceptance and } \\
\text { implementation of solutions }\end{array}$ \\
\hline $\begin{array}{l}\text { 4. Provide participants with relevant information and } \\
\text { actual decision-making power }\end{array}$ & $\begin{array}{l}\text { Give participants actual decision-making power and } \\
\text { provide high-quality, accessible, unbiased background } \\
\text { information. }\end{array}$ & $\begin{array}{l}\text { Information gain } \\
\text { Learning } \\
\text { Mutual gains (win-win) } \\
\text { Flexible solutions } \\
\text { Goal attainment } \\
\text { Increased trust }\end{array}$ \\
\hline $\begin{array}{l}\text { 5. Use professional independent facilitation and } \\
\text { structured methods of information aggregation }\end{array}$ & $\begin{array}{l}\text { Use a competent independent facilitator that can deal } \\
\text { with power imbalances, stimulate active participation of } \\
\text { all actors, and assure fair participation and deliberation } \\
\text { with equal opportunity. Use structured methods of } \\
\text { information aggregation and face to face contact } \\
\text { between participants. }\end{array}$ & $\begin{array}{l}\text { Information gain } \\
\text { Learning } \\
\text { Mutual gains (win-win) } \\
\text { Flexible, sustainable, and socially } \\
\text { equitable solutions } \\
\text { Conflict resolution } \\
\text { Increased trust } \\
\text { Goal attainment }\end{array}$ \\
\hline 6. Promote long-term commitment of all participants & $\begin{array}{l}\text { Successful participation requires long-term commitment } \\
\text { from all participants and realistic economic support for } \\
\text { implementation of solutions }\end{array}$ & $\begin{array}{l}\text { Increased trust and implementation of } \\
\text { solutions }\end{array}$ \\
\hline $\begin{array}{l}\text { 7. Adapt language, location, and process design to the } \\
\text { participants }\end{array}$ & $\begin{array}{l}\text { Use accessible language and forms of information } \\
\text { adapted to the education level of participants. Field } \\
\text { visits or village meetings are often more effective than } \\
\text { seminar presentations at universities or government } \\
\text { buildings. }\end{array}$ & $\begin{array}{l}\text { Increased trust } \\
\text { Increased participation } \\
\text { Learning }\end{array}$ \\
\hline
\end{tabular}

\section{How important are local and national context in determining the outcomes of participatory processes?}

Several studies emphasize the role of context in determining the outcomes of participatory processes (Koontz 2005, Stringer et al. 2007, Blicharska et al. 2011). Most of this research has focused on the socioeconomic, cultural, and institutional contexts within which participation is enacted (Delli Carpini et al. 2004). For example, the distribution of power may impact the nature of the decision that is made, as well as its acceptance, because those who feel disadvantaged by the process may choose to delay or prevent implementation of the decision, for example by taking legal action (Turner and Weninger 2005).

Contrary to the literature, our findings suggest that although a number of mainly localized contextual factors play an important role in determining the outcomes of a participatory process, these are outnumbered by factors linked to process design. This is not to say that context is unimportant in determining the outcomes of participatory processes. The entire discipline of environmental anthropology is devoted to understanding the role of culture in the relationship between people and their environment (Milton 1996, Sanga and Ortalli 2007), while social and institutional complexity and scale need to be taken into account during process design (Singleton 2002, Ferreyra et al. 2008, Armitage et al. 2012). However, our findings suggest that well designed participatory processes, which by definition are flexible and sensitive to cultural factors, are largely transferable across local and national contexts. The adaptability and quality of facilitation in well-designed processes enables them to adjust to context. This was demonstrated by the success and the similar outcomes of a 
participatory process replicated across a wide range of socioeconomic and environmental national contexts in the DESIRE project (Schwilch et al. 2012), and the relatively small number of local contextual factors that significantly correlated with process outcomes in Spain and Portugal, compared with process design factors.

Nevertheless, some local and national contextual factors that affected process outcomes may be difficult to change, e.g., stakeholder fatigue, the lack of a "participation culture" in the society where the process is being implemented, a lack of funding to implement decisions, or distrust between stakeholders and those running the process or those with the power to implement decisions. Some of the most commonly cited reasons for distrust and stakeholder fatigue in our study were lack of immediate personal benefit from participating, frequently changing policies, and bad past experiences of participatory processes that did not effect change. Appreciating these context related factors may facilitate the design of more effective participatory processes to fit specific contexts. For example, where stakeholder fatigue is identified at the outset, it may be possible to alter the timing of events to reduce demands on people's time, or collaborate with other initiatives to reduce the number of different approaches that are made to stakeholders (cf. Sandström et al. 2014), and identify participants who have not been invited to previous workshops.

\section{CONCLUSIONS}

We explicitly linked the process of participation with its outcomes, carefully considering the extent to which context versus process design influences these outcomes. Based on empirical evidence from quantitative and qualitative evaluation of interviews with facilitators and stakeholders engaged in participatory processes in 11 cases from Spain and Portugal and 13 international dryland sites, we identified a range of social and environmental outcomes of stakeholder participation. A small number of local contextual factors influenced the outcomes of participatory processes in Spain and Portugal. However, in the international comparison of an almost identical participatory process replicated across 13 dryland study sites around the world, the outcomes of the participatory process were similar across all sites, despite large variations in context between those sites. Although this finding suggests that variation in national context had little influence on outcomes, this is not to say that context had no effect on outcomes whatsoever. The limited amount of variation in outcomes that was observed across national contexts could be explained by a small number of contextual factors. We therefore conclude that well-designed participatory processes that consider the recommendations from this research, can lead to well-informed, durable, and flexible outcomes across a wide range of contexts. Moreover, through increased trust and ownership over problems and solutions, decisions taken in these processes are more likely to be accepted and implemented, helping to achieve environmental goals more effectively.

Our analysis of cases in widely contrasting local and national contexts suggests that the most important factors determining process outcomes are who participates, how the process and communication among participants is organized, and how the outputs of the process are linked to policy and implementation of solutions. These three aspects reflect Fung's (2006) approach to characterizing stakeholder participation. Local factors such as lack of experience or interest in participation, stakeholder fatigue, and power imbalances, are the principal context-related challenges that may need to be overcome. Professional facilitation and higher levels of participation by a heterogeneous group of stakeholders lead to learning, acceptance, and trust. However, implementation of solutions requires participation of government institutes, while this negatively correlates with learning and trust due to perceived power imbalances. This stresses the need for skilled facilitation and supports the need for separate processes for the participation of government representatives and other stakeholders. In addition to group composition and flexible process design, implementation of solutions depends on a good understanding of the environmental problem by individuals, a cooperative government, and trust between stakeholders.

These findings have important implications when it comes to upscaling of participatory processes because there could be a number of generic "good practices" in terms of design, implementation, and facilitation that should be shared between local and national contexts. Based on the empirical evidence, we identified seven recommendations for participatory processes in management of social-ecological systems: (1) select participants carefully, (2) make participation attractive and easy, (3) foster trust, (4) provide participants with information and decisionmaking power, (5) use professional independent facilitation and structured methods of information aggregation, (6) promote long-term commitment, and (7) adapt language, location, and design to the participants. Although participatory processes will always be challenging, following these recommendations will provide better-informed and sustainable environmental decisions and beneficial social outcomes in a range of decision-making contexts where stakeholders are engaged in management of social-ecological systems.

Although our study provides empirical evidence for a range of perceived outcomes of participation, the measurable impacts of participation on environmental quality and social benefits still require further evaluation. Consideration of a wider range of case studies and variables, perhaps building on the meta-analysis approach used by Newig et al. (2013), may also provide further insight into key factors influencing the outcomes of participatory processes. Alternatively, involving a wider range of participants and beneficiaries in research may provide more in-depth insights into the reasons why and under which conditions these factors are important. The empirical work reported in this paper goes some way toward explaining why participation works (or not), and as such, may provide the building blocks for a more complete and nuanced understanding of participation.

Responses to this article can be read online at: http://www.ecologyandsociety.org/issues/responses. $\mathrm{php} / 8053$

\section{Acknowledgments:}

This research was funded by the British Academy under a Research Development Award led by MR. Parts of this research have been funded by the European Research Council (ERC) through the 
EDGE project as grant to JN (grant 263859-EDGE), and in the framework of the EC-DG RTD- 6th Framework Research Programme (sub-priority 1.1.6.3) - Research on Desertification project DESIRE (037046): Desertification Mitigation and Remediation of land - a global approach for local solutions. JDV acknowledges funding from the Spanish Ministry of Science and Innovation (RYC-2012-10375 \& CGL2013-42009-R) and the Séneca foundation (18933/JLI/13). We warmly thank all the interviewees who were so kind to share their experiences and views with us. Thanks also to Steven Vella for useful feedback on an earlier draft of this paper.

\section{LITERATURE CITED}

Argyris, C., and D. A. Schön. 1978. Organizational learning: a theory of action perspective series on organization development. Addison-Wesley, Reading, Massachusetts.

Armitage, D., R. de Loë, and R. Plummer. 2012. Environmental governance and its implications for conservation practice. Conservation Letters 5(4):245-255. http://dx.doi.org/10.1111/ j.1755-263x.2012.00238.x

Beierle, T. C. 1999. Using social goals to evaluate public participation in environmental decisions. Review of Policy Research 16(3-4):75-103. http://dx.doi.org/10.1111/j.1541-1338.1999. tb00879.x

Beierle, T. C. 2002. The quality of stakeholder-based decisions. Risk Analysis 22(4):739-749. http://dx.doi.org/10.1111/0272-4332.00065

Blicharska, M., K. Isaksson, T. Richardson, and C.-J. Wu. 2011. Context dependency and stakeholder involvement in EIA: the decisive role of practitioners. Journal of Environmental Planning and Management 54(3):337-354 http://dx.doi.org/10.1080/09640$\underline{568.2010 .506077}$

Chambers, R. 1983. Rural development: putting the last first. Pearson Education Limited, New York, New York, USA.

Coglianese, C. 1997. Assessing consensus: the promise and performance of negotiated rulemaking. Duke Law Journal 46:1255-1349. http://dx.doi.org/10.2307/1372989

Collins, K., and R. Ison. 2009. Jumping off Arnstein's ladder: social learning as a new policy paradigm for climate change adaptation. Environmental Policy and Governance 19(6):358-373. http://dx.doi.org/10.1002/eet.523

Cook, B., and U. Kothari. 2001. Participation: the new tyranny? Zed Books, London, UK.

Cook, S. D. N., and H. Wagenaar. 2012. Navigating the eternally unfolding present: toward an epistemology of practice. American Review of Public Administration 42(1):3-38. http://dx.doi. org/10.1177/0275074011407404

Corbin, J. M., and A. Strauss. 1990. Grounded theory research: procedures, canons, and evaluative criteria. Qualitative Sociology 13(1):3-21. http://dx.doi.org/10.1007/bf00988593

Cuppen, E. 2012. Diversity and constructive conflict in stakeholder dialogue: considerations for design and methods. Policy Sciences 45(1):23-46. http://dx.doi.org/10.1007/s11077-011-9141-7

Delli Carpini, M. X., F. L. Cook, and L. R. Jacobs. 2004. Public deliberation, discursive participation, and citizen engagement: a review of the empirical literature. Annual Review of Political Science 7:315-344. http://dx.doi.org/10.1146/annurev. polisci.7.121003.091630

Diduck, A., and A. J. Sinclair. 2002. Public involvement in environmental assessment: the case of the nonparticipant. Environmental Management 29(4):578-588. http://dx.doi.org/10.1007/ $\underline{\mathrm{s} 00267-001-0028-9}$

Dietz, T., and P. C. Stern, editors. 2008. Public participation in environmental assessment and decision-making. National Academies Press, Washington, D.C., USA.

Fazey, I., J. A. Fazey, and D. M. A. Fazey. 2005. Learning more effectively from experience. Ecology and Society 10(2):4. [online] URL: http://www.ecologyandsociety.org/vol10/iss2/art4/

Ferreyra, C., R. C. de Loë, and R. D. Kreutzwiser. 2008. Imagined communities, contested watersheds: challenges to integrated water resources management in agricultural areas. Journal of Rural Studies 24(3):304-321. http://dx.doi.org/10.1016/j. jrurstud.2007.11.001

Fiorino, D. J. 1990. Citizen participation and environmental risk: a survey of institutional mechanisms. Science, Technology, \& Human Values 15(2):226-243. http://dx.doi.org/10.1177/0162243$\underline{99001500204}$

Fung, A. 2006. Varieties of participation in complex governance. Public Administration Review 66:66-75. http://dx.doi.org/10.1111/ j.1540-6210.2006.00667.x

Gerrits, L., and J. Edelenbos. 2004. Management of sediments through stakeholder involvement. Journal of Soils and Sediments 4(4):239-246. http://dx.doi.org/10.1007/bf02991120

Hurlbert, M., and J. Gupta. 2015. The split ladder of participation: a diagnostic, strategic, and evaluation tool to assess when participation is necessary. Environmental Science \& Policy 50:100-113. http://dx.doi.org/10.1016/j.envsci.2015.01.011

Keen, M., and S. Mahanty. 2006. Learning in sustainable natural resource management: challenges and opportunities in the Pacific. Society \& Natural Resources 19(6):497-513. http://dx.doi. org/10.1080/08941920600663896

Kenter, J. O., M. S. Reed, K. N. Irvine, E. O'Brien, E. Brady, R. Bryce, M. Christie, A. Church, N. Cooper, A. Davies, N. Hockley, I. Fazey, N. Jobstvogt, C. Molloy, J. Orchard-Webb, N. Ravenscroft, M. Ryan, and V. Watson. 2014. UK national ecosystem assessment follow-on. Work package report 6: shared, plural and cultural values of ecosystems. The United Nations Environment Programme's World Conservation Monitoring Centre, Living With Environmental Change, UK.

Koontz, T. M. 2005. We finished the plan, so now what? Impacts of collaborative stakeholder participation on land use policy. Policy Studies Journal 33(3):459-481. http://dx.doi.org/10.1111/ j.1541-0072.2005.00125.x

Leach, W. D., and P. A. Sabatier. 2005. Are trust and social capital the keys to success? Watershed partnerships in California and Washington. Pages 233-58 in P. A. Sabatier, W. Focht, M. Lubell, Z. Trachtenberg, A. Vedlitz, and M. Matlock, editors. Swimming upstream. Collaborative approaches to watershed management. MIT Press, Cambridge, Massachusetts, USA. 
Lind, E. A., and T. R. Tyler. 1988. The social psychology of procedural justice. Plenum, New York, New York, USA. http:// dx.doi.org/10.1007/978-1-4899-2115-4

Macnaghten, P., and M. Jacobs. 1997. Public identification with sustainable development: investigating cultural barriers to participation. Global Environmental Change 7(1):5-24. http://dx. doi.org/10.1016/s0959-3780(96)00023-4

Milton, K. 1996. Environmentalism and cultural theory: exploring the role of anthropology in environmental discourse. Routledge, London, UK. http://dx.doi.org/10.4324/9780203205440

Newig, J. 2012. More effective natural resource management through participatory governance? Taking stock of the conceptual and empirical literature - and moving forward. Pages 46-68 in K. Hogl, E. Kvarda, R. Nordbeck, and M. Pregernig, editors. Environmental governance: the challenge of legitimacy and effectiveness. Edward Elgar, Cheltenham, UK. http://dx.doi. org/10.4337/9781849806077.00011

Newig, J., A. Adzersen, E. Challies, O. Fritsch, and N. Jager. 2013. Comparative analysis of public environmental decision-making processes - a variable-based analytical scheme. Discussion Paper No. 37/13. Institut Für Umweltkommunikation, Lüneburg, Germany. http://dx.doi.org/10.2139/ssrn.2245518

Newig, J., and O. Fritsch. 2009a. Environmental governance: participatory, multi-level - and effective? Environmental Policy and Governance 19(3):197-214. http://dx.doi.org/10.1002/eet.509

Newig, J., and O. Fritsch. 2009b. More input - better output: does citizen involvement improve environmental governance? Pages 205-224 in I. Blühdorn, editor. In search of legitimacy: policy making in Europe and the challenge of complexity. Barbara Budrich, Opladen, Farmington Hills, Michigan, USA.

Pahl-Wostl, C., and M. Hare. 2004. Processes of social learning in integrated resources management. Journal of Community \& Applied Social Psychology 14(3):193-206. http://dx.doi. org/10.1002/casp.774

Pahl-Wostl, C., J. Sendzimir, P. Jeffrey, J. Aerts, G. Berkamp, and K. Cross. 2007. Managing change toward adaptive water management through social learning. Ecology and Society 12 (2):30. http://www.ecologyandsociety.org/vol12/iss2/art30/

Pretty, J. N. 1995. Participatory learning for sustainable agriculture. World Development 23:1247-1263. http://dx.doi. org/10.1016/0305-750X(95)00046-F

Reed, M. S. 2008. Stakeholder participation for environmental management: a literature review. Biological Conservation 141 (10):2417-2431. http://dx.doi.org/10.1016/j.biocon.2008.07.014

Reed, M. S., A. C. Evely, G. Cundill, I. Fazey, J. Glass, A. Laing, J. Newig, B. Parrish, C. Prell, C. Raymond, and L. C. Stringer. 2010. What is social learning? Ecology and Society 15(4):r1. [online] URL: http://www.ecologyandsociety.org/vol15/iss4/ resp1/

Reed, M. S., A. Graves, N. Dandy, H. Posthumus, K. Hubacek, J. Morris, C. Prell, C. H. Quinn, and L. C. Stringer. 2009. Who's in and why? A typology of stakeholder analysis methods for natural resource management. Journal of Environmental Management 90(5):1933-1949. http://dx.doi.org/10.1016/j.

jenvman.2009.01.001
Renn, O., T. Webler, and P. Wiedemann. 1995. The pursuit of fair and competent citizen participation. Pages 339-369 in O. Renn, T. Webler, and P. Wiedemann, editors. Fairness and competence in citizen participation: evaluating models for environmental discourse. Kluwer Academic, Dodrecht, The Netherlands. http:// dx.doi.org/10.1007/978-94-011-0131-8_20

Rowe, G., and L. J. Frewer. 2000. Public participation methods: a framework for evaluation. Science, Technology, \& Human Values 25(1):3-29. http://dx.doi.org/10.1177/016224390002500101

Sandström, A., B. Crona, and Ö. Bodin. 2014. Legitimacy in comanagement: the impact of preexisting structures, social networks and governance strategies. Environmental Policy and Governance 24(1):60-76. http://dx.doi.org/10.1002/eet.1633

Sanga, G., and G. Ortalli, editor. 2007. Nature knowledge: ethnoscience, cognition, identity. Berghahn Books, New York, New York, USA.

SAS. 2011. SAS Online Doc version 9. SAS Institute, Cary, North Carolina, USA.

Scott, A. 2011. Focussing in on focus groups: effective participative tools or cheap fixes for land use policy? Land Use Policy 28:684-694. http://dx.doi.org/10.1016/j.landusepol.2010.12.004

Schwilch, G., F. Bachmann, and H. P. Liniger. 2009. Appraising and selecting conservation measures to mitigate desertification and land degradation based on stakeholder participation and global best practices. Land Degradation \& Development 20 (3):308-326. http://dx.doi.org/10.1002/ldr.920

Schwilch, G., F. Bachmann, S. Valente, C. Coelho, J. Moreira, A. Laouina, M. Chaker, M. Aderghal, P. Santos, and M. S. Reed. 2012. A structured multi-stakeholder learning process for Sustainable Land Management. Journal of Environmental Management 107(30):52-63. http://dx.doi.org/10.1016/j. jenvman.2012.04.023

Siebenhüner, B., and J. Suplie. 2005. Implementing the access and benefit-sharing provisions of the CBD: a case for institutional learning. Ecological Economics 53:507-522. http://dx.doi. org/10.1016/j.ecolecon.2004.10.012

Singleton, S. 2002. Collaborative environmental planning in the American West: the good, the bad and the ugly. Environmental Politics 11(3):54-75. http://dx.doi.org/10.1080/714000626

Stanghellini, P. S. L. 2010. Stakeholder involvement in water management: the role of the stakeholder analysis within participatory processes. Water Policy 12(5):675-694 http://dx.doi. org/10.2166/wp.2010.004

Stringer, L. C., and A. J. Dougill. 2013. Channelling science into policy: enabling best practices from research on land degradation and sustainable land management in dryland Africa. Journal of Environmental Management 114:328-335. http://dx.doi.org/10.1016/ j.jenvman.2012.10.025

Stringer, L. C., S. Scrieciu, and M. S. Reed. 2009. Biodiversity, land degradation, and climate change: participatory planning in Romania. Applied Geography 29:77-90. http://dx.doi.org/10.1016/ j.apgeog.2008.07.008 
Stringer, L. C., C. Twyman, and D. S. G. Thomas. 2007. Combating land degradation through participatory means: the case of Swaziland. Ambio 36(5):387-393. http://dx.doi. org/10.1579/0044-7447(2007)36[387:cldtpm]2.0.co;2

Turner, M., and Q. Weninger. 2005. Meetings with costly participation: an empirical analysis. Review of Economic Studies 72(1):247-268. http://dx.doi.org/10.1111/0034-6527.00331

Valente, S. 2013. Stakeholder participation in Sustainable Forest Management in fire-prone areas. Dissertation, University of Aveiro, Portugal.

Wenger, E. 2000. Communities of practice and social learning systems. Organization 7(2):225-246. http://dx.doi. org/10.1177/135050840072002

Young, J. C., J. R. A. Butler, A. Jordan, and A. D. Watt. 2012. Less government intervention in biodiversity management: risks and opportunities. Biodiversity and Conservation 21(4):1095-1100. http://dx.doi.org/10.1007/s10531-012-0243-0

Young, J. C., A. Jordan, K. R. Searle, A. Butler, D. S. Chapman, P. Simmons, and A. D. Watt. 2013. Does stakeholder involvement really benefit biodiversity conservation? Biological Conservation 158:359-370. http://dx.doi.org/10.1016/j.biocon.2012.08.018 


\section{Appendix 1}

Questionnaire that was used to document the process design, outcomes, and context parameters of participatory processes performed in Spain, Portugal, and 13 DESIRE dryland cases globally.

Section 1: background information

1) Case study name (project \& country):

2) Additional literature used:

Author type (1=Mediator, 2=Participant, 3=Researcher (inside), 4=Researcher (externally)

(code 3, 8)

3) In which group would you place yourself (more than 1 possible)?

[ ] farmer

[ ] representing a farmers organisation

[ ] representing a nature conservation organisation

[] representing a governmental organisation.

At what level: [ ] local [ ] regional [ ] national [ ] international

[] private company

[ ] scientist

[ ] other:

4) What is your age? [ ] $<26$

[ ] 26-35

[ ] $36-45 \quad$ [ ] $46-55$

[ ] $56+$

5) [] Male [ ] Female

6) When did the process start (year, month)?

7) When did the process end (year, month)?

8) When was a decision made (year, month)?

9) What was your role in the process?

\section{Section 2: participants' general impressions (open questions)}

10) What 3 factors do you think are required to make participation successful in achieving goals in environmental management?

11) What are the main challenges to participation in environmental management in the context of your project?

12) Based on your experience, what do you think are the most important outcomes of participation? 


\section{Appendix 1}

13) Can you give a short description of the environmental problem and what is at stake for environmental quality and society, both on and off-site? 


\section{Appendix 1}

\section{Section 3: Results}

14) To what degree did participants provide information (technical information as well as information about general aims of the actors) used for developing the output?

$$
\begin{array}{llllll}
\text { low } & & \rightarrow & \rightarrow & \text { high } & \\
{[] 0} & {[] 1} & {[] 2} & {[] 3} & {[] 4} & \text { []not relevant }
\end{array}
$$

15) To what degree did the process develop mutual gains (win-win solutions)?

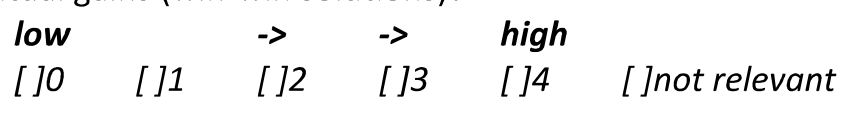

16) To what extent do the environmental outputs meet the goals specified at the beginning of the decision-making process? $(0=$ the initiator's environmental goal was fulfilled; $-4=$ the output is much worse for the environment than what the initiator sought; $4=$ the output is much better for the environment than the initiator aimed at)

$$
\begin{array}{lllllllll}
\multicolumn{2}{r}{\text { result }<<\text { goal }} & \rightarrow & \rightarrow & & \rightarrow & \rightarrow & \multicolumn{2}{r}{\text { result>>goal }} \\
{[]-4} & {[]-3} & {[]-2} & {[]-1} & {[] 0} & {[] 1} & {[] 2} & {[] 3} & {[] 4}
\end{array}
$$

17) Please rate the feasibility of the agreed measures in the sense of monitoring, controlling, and sanction possibilities.

$\begin{array}{lllll}\text { low } & & \rightarrow & \rightarrow & \text { high } \\ {[] 0} & {[] 1} & {[] 2} & {[] 3} & {[] 4}\end{array} \quad$ []not relevant

18) To what degree is the output (i.e. selected solution) flexible, incremental and adaptive to new knowledge or changing conditions?

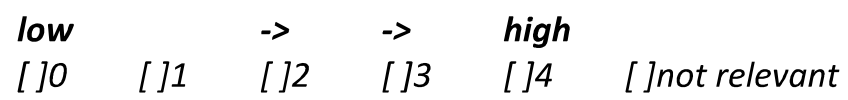

19) To what degree do the selected solutions address social, economic and environmental interests as well as a long-term perspective?

$\begin{array}{lllll}\text { low } & & \rightarrow & \rightarrow & \text { high } \\ {[] 0} & {[] 1} & {[] 2} & {[] 3} & {[] 4}\end{array} \quad$ []not relevant

\begin{tabular}{|c|c|c|c|c|c|c|}
\hline intensified & $\rightarrow$ & $\rightarrow$ & & $\rightarrow$ & $\rightarrow$ & resolved \\
\hline[]$-4 \quad[]-3$ & {[]$-2$} & [ ]-1 & {[] 0} & {[] 1} & {[] 2} & {[] 3} \\
\hline
\end{tabular}

20) Please indicate the degree to which an existing conflict was resolved through the process $(-4=$ conflict severely intensified or developed; $0=$ degree of conflict did not change; $4=$ conflict was fully resolved).

21) Please rate the acceptance of the decision by each of the following groups.
a) those who have to comply with and implement the decision:
low
$\rightarrow \quad \rightarrow \quad$ high
b) the competent authority:
$\left.\left[\begin{array}{llllll}] 0 & {[}\end{array}\right] 1\right] 2 \quad[] 3 \quad[] 4 \quad[$ ]not relevant
c) other participants:

$\begin{array}{llllll}{[] 0} & {[] 1} & {[] 2} & {[] 3} & {[] 4} & \text { []not relevant } \\ {[] 0} & {[] 1} & {[] 2} & {[] 3} & {[] 4} & \text { []not relevant }\end{array}$

22) To what extent did participants learn and did they better understand the problem after the process? 


\section{Appendix 1}

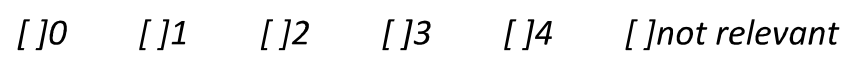

23) For each of the following indicate to what extent trust was built-up (positive values) or lessened (negative values).

a) Amongst general public:

$$
\begin{array}{llllllll}
\text { less trust } \quad \rightarrow & -> & -> & -> & \text { more trust }
\end{array}
$$

$$
[]-4 \quad[]-3 \quad[]-2 \quad[]-1 \quad[] 0 \quad[] 1 \quad[] 2 \quad[] 3 \quad[] 4
$$

b) Between public and the competent authority:

$$
[]-4 \quad[]-3 \quad[]-2 \quad[]-1 \quad[] 0 \quad[] 1 \quad[] 2 \quad[] 3 \quad[] 4
$$

c) Between competent authority and scientists:

$$
[]-4 \quad[]-3 \quad[]-2 \quad[]-1 \quad[] 0 \quad[] 1 \quad[] 2 \quad[] 3 \quad[] 4
$$

\begin{tabular}{|c|c|c|c|c|c|}
\hline irrational & $\rightarrow$ & $->$ & $\rightarrow$ & $\rightarrow$ & rational \\
\hline[]$-4 \quad[]-3$ & {[]$-2$} & {[]$-1$} & {[] 1} & {[] 2} & \\
\hline
\end{tabular}

d) Between public and scientists:

$$
\left[\begin{array}{lllllllll}
-4 & {[]-3} & {[]-2} & {[]-1} & {[] 0} & {[] 1} & {[] 2} & {[] 3} & {[] 4}
\end{array}\right.
$$

24) To what extent was the output economically rational?

25) To what extent was the output socially equitable?

\begin{tabular}{lllllllll} 
non-equitable & $\rightarrow$ & $\rightarrow$ & & $\rightarrow$ & $\rightarrow$ & \multicolumn{2}{c}{ equitable } \\
{[]$-4$} & {[]$-3$} & {[]$-2$} & {[]$-1$} & {[] 0} & {[] 1} & {[] 2} & {[] 3} & {[] 4}
\end{tabular}

26) Please rate the degree to which the selected solutions, recommendations and decisions are being (or will most probably be) implemented and complied with.

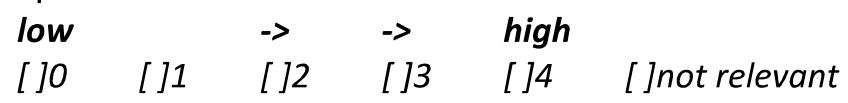

\section{Section 4: Actual process}

27) To what degree were important leaders involved, i.e. people whose opinion stakeholders respect in relation to the specific issue?

$\begin{array}{lllll}\text { low } & & \rightarrow & \rightarrow & \text { high } \\ {[] 0} & {[] 1} & {[] 2} & {[] 3} & {[] 4}\end{array} \quad$ []not relevant

28) To what degree were those who will have to implement the output involved?

$\begin{array}{lllll}\text { low } & & \rightarrow & \rightarrow & \text { high } \\ {[] 0} & {[] 1} & {[] 2} & {[] 3} & {[] 4}\end{array} \quad$ []not relevant

29) To what degree was there a 'legitimate' representation of all affected parties?

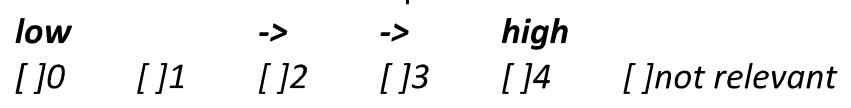

30) To what degree was there an imbalance of power among participants during the process?

low $\quad \rightarrow \quad \rightarrow \quad$ high 


\section{Appendix 1}

$\left[\begin{array}{llllll}] 0 & {[}\end{array}\right] 12 \quad\left[\begin{array}{ll}3 & {[}\end{array}\right] 4 \quad$ [ ]not relevant

31) To what degree did participants not representing government institutions influence decisions made during the process?

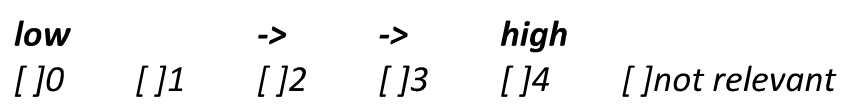

32) To what extent did non-state participants receive information from state and non-state participants?

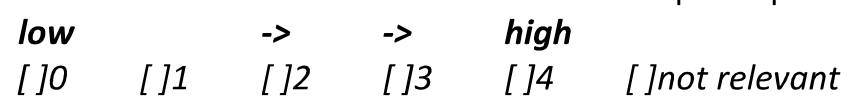

33) Please rate the degree of information exchange taking place through face-to-face discussions between all participants (state and non-state)?

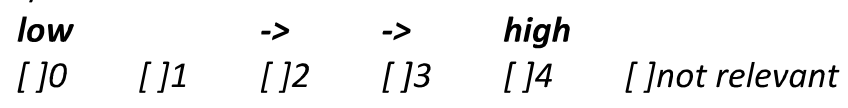

34) To what degree did deliberation with equal opportunities to contribute take place amongst participants?

$\begin{array}{lllll}\text { low } & & \rightarrow & \rightarrow & \text { high } \\ {[] 0} & {[] 1} & {[] 2} & {[] 3} & {[] 4}\end{array}$ []not relevant

35) To what degree were people permitted to initiate discourse and to participate in discourse and decision making during the process?

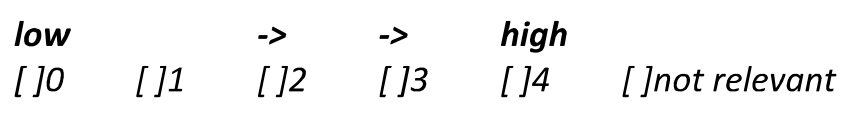

Section 5: Process design

36) To what degree was each of the following a rationale for using a participatory approach?

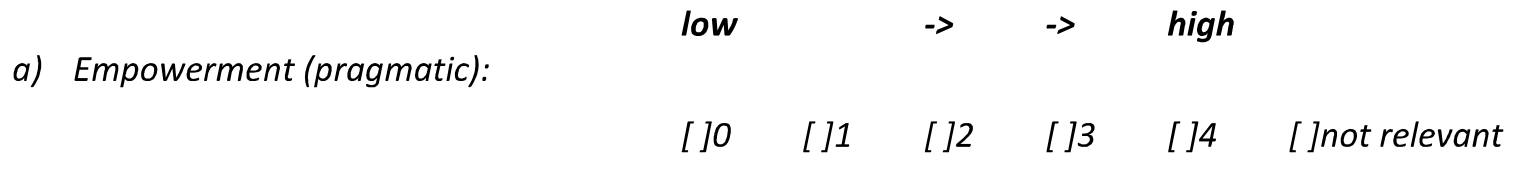

b) democratic legitimacy (normative):

$\left.\left[\begin{array}{llllll}] 0 & {[}\end{array}\right] 1\right] \quad[] 3 \quad[] 4 \quad$ [ ]not relevant

c) effective/efficient achievement of goals:

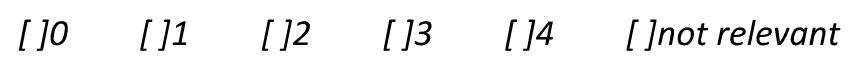

d) conflict resolution:

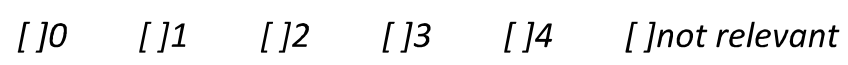

e) fulfilment of legal requirements:

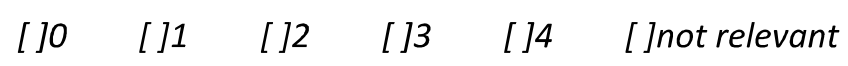

f) achievement of environmental benefits:

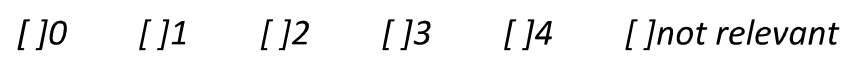




\section{Appendix 1}

37) Was the process bottom-up (i.e. local stakeholders) or top-down (i.e. external stakeholders) initiated? Any value in between is also possible.

$\begin{array}{llll}\text { Bottom-up } & \rightarrow & \rightarrow & \text { Top-down } \\ {[] 0 \quad[] 1} & {[] 2} & {[] 3} & {[] 4}\end{array}$

38) Was the responsible government institute (i.e. competent authority) the main initiator of the process?

[] Yes [] No

39) To what extent did the competent authority participate in the process:

\begin{tabular}{llllll} 
never & $\rightarrow$ & $\rightarrow$ & $->$ & \multicolumn{2}{c}{ constantly } \\
{[] 0} & {[] 1} & {[] 2} & {[] 3} & {[] 4} & []not relevant
\end{tabular}

40) To what extent did the competent authority act as facilitator, moderator or mediator in the process?

\begin{tabular}{llllll} 
never & $\rightarrow$ & $\rightarrow$ & $\rightarrow$ & \multicolumn{2}{l}{ constant } \\
{[] 0} & {[] 1} & {[] 2} & {[] 3} & {[] $4 \quad$ []not relevant }
\end{tabular}

41) To what degree was the method of participant selection controlled? ( $0=$ 'anyone' could participate; $4=$ particular participants were selected)

$$
\begin{aligned}
& \text { low } \quad \rightarrow \quad \rightarrow \quad \text { high } \\
& {\left[\begin{array}{llllll}
] 0 & {[] 1} & {[] 2} & {[] 3} & {[] 4} & \text { []not relevant }
\end{array}\right.}
\end{aligned}
$$

42) If participant selection was controlled, was this on the basis of a systematic assessment of who was likely to hold a stake in the decisions being made (i.e. on the basis of a stakeholder analysis)?

$$
\text { [] Yes [] No [ ]not relevant }
$$

43) To what degree were participants given the opportunity to self-design the process?

$$
\begin{array}{llllll}
\text { low } & & \rightarrow & \rightarrow & \text { high } & \\
{[] 0} & {[] 1} & {[] 2} & {[] 3} & {[] 4} & \text { []not relevant }
\end{array}
$$

44) To what degree was a specific method used (questionnaires, interviews, workshops) to facilitate knowledge exchange between participants? The more structured the method, the higher the score below.

$$
\begin{array}{llllll}
\text { low } & & \rightarrow & \rightarrow & \text { high } & \\
{[] 0} & {[] 1} & {[] 2} & {[] 3} & {[] 4} & \text { []not relevant }
\end{array}
$$

45) To what extent was aggregation of information from participants facilitated/structured? (e.g. through voting, classification, decision support system...)

$\begin{array}{lllll}\text { low } & & \rightarrow & \rightarrow & \text { high } \\ {[] 0} & {[] 1} & {[] 2} & {[] 3} & {[] 4}\end{array} \quad$ []not relevant

46) To what extent was the process moderated or mediated? $(0=$ not facilitated; $4=$ fully mediated $)$

$$
\begin{aligned}
& \text { low } \quad \rightarrow \quad \rightarrow \quad \text { high } \\
& {\left[\begin{array}{llllll}
] 0 & {[] 1} & {[] 2} & {[] 3} & {[] 4} & \text { []not relevant }
\end{array}\right.}
\end{aligned}
$$

47) What kind of participatory processes were used (drop in centre, public hearing, questionnaire...): 


\section{Appendix 1}

\section{Section 6: Contextual}

48) Is there any existing law or agreement that regulates the policy field of the environmental problem under consideration?

[ ]Yes [] No

49) To what degree were the existing laws and agreements uncertain (i.e. frequently changing) or ambiguous (i.e. multi- interpretable)?

$$
\begin{array}{lllll}
\text { uncertain } & \rightarrow & -> & \multicolumn{1}{l}{\text { certain }} \\
{[] 0} & {[] 1} & {[] 2} & {[] 3} & {[] 4 \quad \text { []not relevant }}
\end{array}
$$

50) To what degree was autonomous decision-making at the problem scale possible in the context of

\begin{tabular}{|c|c|c|c|}
\hline no room & $->$ & $->$ & open \\
\hline[] $0 \quad[] 1$ & {[] 2} & {[] 3} & {[] 4} \\
\hline
\end{tabular}
your project? (From no room for manoeuvre (0) to fully autonomous at the process level (4)).

51) What was the number of significantly involved different levels of governance? (e.g. municipal + catchment + state + national + supranational authority $=5$ ). To be counted as significantly involved, an agency must have been present at least at one third of the meetings. [ ]

52) At what governance level did the process take place?

[ ]0 (municipal) []1 (regional) []2 (province) []3 (national) [ ]4 (international)

[ ]not relevant

53) For each of the following groups indicate how important they were to (help) bring the problem onto the agenda?

( 0 = not important; 4 = very important)
a) a previous political decision (a law):
$\left[\begin{array}{llll}] 0 & {[}\end{array}\right] 1 \quad[] 2 \quad[] 3$
[ ]4
[]not relevant
b) the competent authority:
$\left[\begin{array}{llllll}] 0 & {[}\end{array}\right] 1 \quad[] 2 \quad[] 3 \quad[] 4 \quad$ []not relevant
c) general public:

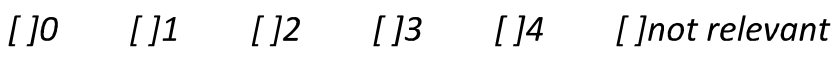
d) research or development project:
$[10 \quad[]$
$\left[\begin{array}{ll}{[} & {[}\end{array}\right]$
[ ] [ ] not relevant

54) For each of the following indicate how well social networks are functioning. Negative values indicate non functioning networks and distrust. Positive values mean functioning networks and good trust base amongst groups. $\quad(-4=$ not functioning, no trust; 4 = functioning, high trust)

a) Amongst general public:

$$
\left[\begin{array}{lllllllll}
{[-4} & {[]-3} & {[]-2} & {[]-1} & {[] 0} & {[] 1} & {[] 2} & {[] 3} & {[] 4}
\end{array}\right.
$$

b) Between public and the competent authority:

$$
\left[\begin{array}{lllllllll}
{[-4} & {[]-3} & {[]-2} & {[]-1} & {[] 0} & {[] 1} & {[] 2} & {[] 3} & {[] 4}
\end{array}\right.
$$

c) Between competent authority and scientists:

$$
\left[\begin{array}{lllllllll}
{[]-4} & {[]-3} & {[]-2} & {[]-1} & {[] 0} & {[] 1} & {[] 2} & {[] 3} & {[] 4}
\end{array}\right.
$$

d) Between public and scientists:

$\left[\begin{array}{lllllllll}{[]-4} & {[]-3} & {[]-2} & {[]-1} & {[] 0} & {[] 1} & {[] 2} & {[] 3} & {[] 4}\end{array}\right.$




\section{Appendix 1}

55) To what degree was participation institutionalized and common practice in the local context? (code 57)

$\begin{array}{llll}\text { uncommon } & \rightarrow & \rightarrow & \text { very common } \\ {[] 0 \quad[] 1} & {[] 2} & {[] 3} & {[] 4}\end{array}$

56) Please indicate to what extent the environmental problem of your project is related to:

$(0=$ not important; $\mathbf{4}=$ very important $)$

$\begin{array}{lllllllll}\text { a) } & \text { nature conservation (e.g. biodiversity): } & {[] 0} & {[] 1} & {[] 2} & {[] 3} & {[] 4} & \text { []not relevant } \\ \text { b) human health (e.g. pollution): } & {[] 0} & {[] 1} & {[] 2} & {[] 3} & {[] 4} & \text { []not relevant } \\ \begin{array}{l}\text { c) exploitation of scarce natural } \\ \text { resources: }\end{array} & {[] 0} & {[] 1} & {[] 2} & {[] 3} & {[] 4} & \text { []not relevant }\end{array}$

57) How complex are the environmental problem and its possible solutions?

$\begin{array}{lllll}\text { simple } & \rightarrow & \rightarrow & \text { very complex } \\ {[] 0} & {[] 1} & {[] 2} & {[] 3} & {[] 4 \quad \text { []not relevant }}\end{array}$

58) Please indicate how much public attention there was for the problem before beginning of the decision process (media attention).

$\begin{array}{llll}\text { no attention } & \rightarrow & \rightarrow & \text { full attention } \\ {[] 0 \quad[] 1} & {[] 2} & {[] 3} & {[] 4 \quad \text { []not relevant }}\end{array}$

59) To what degree was there potential for a conflict of values as indicated for example by an actual dispute among stakeholders?

$$
\begin{array}{lllll}
\text { low } & & \rightarrow & \rightarrow & \text { high } \\
{[] 0} & {[] 1} & {[] 2} & {[] 3} & {[] 4}
\end{array} \text { []not relevant }
$$

60) To what degree was there a conflict over where a certain problem should be solved?

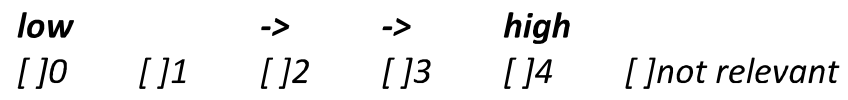

61) How many people are affected by the problem?

62) To what degree is there a win-win potential?

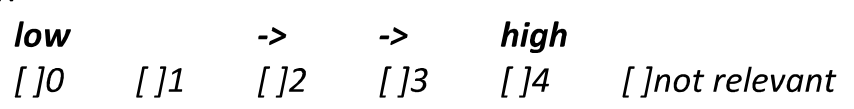

63) Please indicate to what extent each of the following were cooperative towards the process and how well did they understand the environmental issue at stake:

a) government agencies:

$$
\text { low } \quad \rightarrow \quad \rightarrow \quad \text { high }
$$

$\begin{array}{lllllll}\text { Cooperative: } & {[] 0} & {[] 1} & {[] 2} & {[] 3} & {[] 4} & \text { []not relevant } \\ \text { Understanding: } & {[] 0} & {[] 1} & {[] 2} & {[] 3} & {[] 4} & {[] \text { not relevant }}\end{array}$

b) private enterprises:

$\begin{array}{lllllll}\text { Cooperative: } & {[] 0} & {[] 1} & {[] 2} & {[] 3} & {[] 4} & {[\text { ]not relevant }} \\ \text { Understanding: } & {[] 0} & {[] 1} & {[] 2} & {[] 3} & {[] 4} & {[\text { ]not relevant }}\end{array}$

c) civil society organisations: 


\section{Appendix 1}

$\begin{array}{lllllll}\text { Cooperative: } & {[] 0} & {[] 1} & {[] 2} & {[] 3} & {[] 4} & {[\text { ]not relevant }} \\ \text { Understanding: } & {[] 0} & {[] 1} & {[] 2} & {[] 3} & {[] 4} & \text { []not relevant }\end{array}$

d) individuals (e.g. land users):

$\begin{array}{lllllll}\text { Cooperative: } & {[] 0} & {[] 1} & {[] 2} & {[] 3} & {[] 4} & {[\text { ]not relevant }} \\ \text { Understanding: } & {[] 0} & {[] 1} & {[] 2} & {[] 3} & {[] 4} & \text { []not relevant }\end{array}$

64) Is there anything else we should need to know? 